\title{
Cumulative sitting time as discriminator of overweight, obesity, abdominal obesity and lipid disorders in nursing university
}

\section{Tempo sentado acumulado como discriminador de sobrepeso, obesidade, obesidade abdominal $e$ alterações lipídicas em universitárias de enfermagem}

Fernanda Carneiro Mussi ${ }^{1}$
Francisco José Gondim Pitanga
Cláudia Geovana da Silva Pires

Abstract - There is evidence demonstrating that prolonged sitting time is relevant risk factors for metabolic and cardiovascular disorders. The aim of this study was to identify the discriminatory power and propose cumulative sitting time cutoff points for overweight, obesity, abdominal obesity and lipid disorders in nursing university students. A cross-sectional study of 137 women, nursing students from a public university in Salvador, Bahia, Brazil. Data were obtained by applying specific forms, laboratory and anthropometric measurements. The predictive power and cutoff points of sitting time for the outcomes of interest were identified by receiver operating characteristic curves (ROC). A 95\% confidence interval was established. Sitting time for a day of the week was a good discriminator of abdominal obesity: area under the ROC curve (AUC) $=0.66$ (0.57-0.75). No AUC with statistical significance were found to discriminate overweight and total obesity. Sitting time over the weekend showed no discriminatory power for overweight, obesity or abdominal obesity. Sitting time during the week or weekend did not discriminate lipid abnormalities. Sitting time for 8 hours or more a day during the week discriminates the presence of abdominal obesity. The sitting time during the week of 8 hours accumulated per day discriminates abdominal obesity in undergraduate nursing. It is suggested that educational institutions establish measures to encourage a reduction in this sedentary behavior.

Key words: Lipids; Obesity; Sedentary lifestyle.

Resumo - Existem evidências de que o prolongado tempo sentado é um relevante fator de risco para agravos metabólicos e cardiovasculares. Objetivou-se identificar o poder discriminatório e propor pontos de corte do tempo sentado acumulado para sobrepeso, obesidade, obesidade abdominal e alteraçôes lipídicas em estudantes universitárias de enfermagem. Estudo transversal realizado com 137 mulheres, estudantes de enfermagem de uma universidade pública em Salvador, Babia, Brasil. Os dados foram obtidos pela aplicação de formulários específicos, avaliação laboratorial e antropométrica. O poder preditivo e os pontos de corte do tempo sentado para os desfechos de interesse foram identificados por meio das curvas Receiver Operating Characteristic (ROC). Utilizou-se intervalo de confiança a $95 \%$. O tempo sentado durante a semana foi um bom discriminador da presença de obesidade abdominal: área sob a curva $R O C(A C R)=0.66$ (0.57-0.75). Não foram observadas ACR com significância estatística para discriminar sobrepeso e obesidade total. O tempo sentado no final de semana não apresentou poder discriminatório para excesso de peso, obesidade ou obesidade abdominal. O tempo sentado durante ou no final de semana não discriminou as alteraçôes lipidicas. Ficar sentado a partir de 8 horas acumuladas por dia, durante a semana, discrimina a presença de obesidade abdominal. O tempo sentado durante a semana de 8 horas acumuladas por dia discriminou a obesidade abdominal em universitárias de enfermagem. Sugere-se que as instituições de formação incorporem ações de incentivo a redução deste comportamento sedentário.

Palavras-chave: Estilo de vida sedentário; Lipideos; Obesidade.
1 Universidade Federal da Bahia. Escola de Enfermagem. Salvador-BA. Brasil.

2 Universidade Federal da Bahia. Faculdade de Educação. Departamento de Educação Física. Salvador-BA. Brasil.

3 Universidade Federal da Bahia. Escola de Enfermagem. Salvador-Ba. Brasil.

Received: 19 October 2016 Accepted: 23 February 2017 


\section{INTRODUCTION}

There is ample evidence demonstrating that prolonged sitting time is relevant risk factors for metabolic and cardiovascular disorders ${ }^{1-6}$. A recent Australian study showed that prolonged sitting time is a risk factor for all causes of mortality ${ }^{7}$.

In relation to weight gain and obesity associated with sitting time, a longitudinal study demonstrated greater weight variation in women whose sitting time increased during follow-up ${ }^{8}$. In addition, there are reports that reduced sedentary behavior in leisure time may be as important as increased physical activity as a strategy against obesity in adults .

Recent research has shown that sedentary behavior, both prolonged sitting time and screen time discriminate and are associated with overweight and obesity in children, adolescents and adults ${ }^{10-11 .}$

Although research is in the early stages, there is compelling evidence of an association between sedentary behavior and metabolic and cardiovascular health. For example, during sedentary activity significant reductions are observed in muscle liproprotein lipase (LPL) activity, the key enzyme that regulates lipid metabolism ${ }^{12}$.

Undergraduate students exhibit very high levels of sedentary behavior, mainly as a consequence of the prolonged sitting time required to complete academic assignments ${ }^{13}$. As teachers of a public university, we observed nursing students under conditions favorable to sedentary behavior as a result of the extensive workload of the course in the classroom and engaging in extraclass activities such as scientific initiation, extension and monitoring projects, demanding longer study time in libraries and continued use of the computer.

In addition, some studies have demonstrated an association between sedentary behavior and overweight in university students ${ }^{14}$, as well as associations between sedentary behavior and different health outcomes in adults in general ${ }^{15}$.

Establishing the quantitative relationship between sitting time and overweight, obesity, abdominal obesity and lipid disorders may help professors, professionals and public health administrators implement new measures, that is, in addition to physical activity, there may also be suggestions for reducing sitting time, especially in academic settings, since there are few publications on the subject with university students. Educational strategies and university policies can also be considered to prevent these cardiovascular risk factors.

Thus, the aim of the present study was to identify the discriminatory power and propose sitting time cutoff points for overweight, obesity, abdominal obesity and lipid disorders in university students.

\section{METHODOLOGICAL PROCEDURES}

This cross-sectional study was conducted at the School of Nursing of a public university in Salvador, Brazil. 


\section{Sample}

This is an integral study of a matrix project that compared the exposure of undergraduate nursing to cardiovascular risk factors. In 2011, 106 students were enrolled in the first year and 81 in the senior year of the course (161 women and $26 \mathrm{men}$ ). A total of 137 women (87.5\%), aged 18 years or older agreed to take part in the study. Only women were included considering the small number of men and to avoid gender bias.

The power of this study was estimated for a mean prevalence between cardiovascular risk factors of $35 \%$, and a mean difference in the prevalence of risk factors for sedentary behavior between groups (first and last year) of $8 \%$. The significance level adopted was $5 \%$ and a test power of $94.1 \%$ was obtained.

The study complied with national and international ethical guidelines regarding research with human beings. The study was approved by the Research Ethics Committee of the UFBA (University Federal of Bahia) School of Nursing under protocol no. 024/2010.

\section{Data collection}

- Procedures adopted in the student approach

Data were collected between July and November 2011 at the UFBA School of Nursing. Students were initially approached with a classroom presentation by the researchers, who explained the importance of the study, the objectives, procedures to follow, as well as the benefits and risks of taking part. Participants were also given the opportunity to ask questions before giving their informed consent. After agreeing to participate in the research and sign the informed consent, other dates were scheduled for blood collection, anthropometric measurements and application of the sitting time instrument. Subjects were instructed to fast for 12 hours, including water, and not to engage in physical exercise or consume alcoholic beverages in the 24 hours preceding blood collection and anthropometric measures.

At the second meeting, the students were received in a private room at the School of Nursing, at the stipulated time. First, anthropometric measures were taken and blood was collected. The instrument was then applied to collect data on sitting time via an interview.

\section{- Evaluation of Sitting Time}

The sitting time was evaluation with semi-structured questions to collect information on sitting time. This was reported in hours/day and assessed by the following questions: a) On a normal weekday how much time on average do you spend on a cell phone, watching television, playing video games, a computer, attending classes or performing academic tasks; b) On weekends, how much time per day, on average do you spend on a cell phone, watching television, playing video games, a computer, attending classes or performing academic tasks? 


\section{- Blood collection and lipid profile dosing}

Blood was collected by a clinical analysis laboratory contracted for the study. Venipuncture was conducted by a laboratory technician in the presence of a biochemist and one of the researchers in order to determine biochemical levels of total cholesterol (TC), low-density lipoproteins (LDL-c), highdensity lipoproteins (HDL-c), and triglycerides (TG). The material was analyzed by the clinical analysis laboratory and serum TC, HDL-c and TG levels were determined using enzyme methods (Roche Diagnostics), and LDL-c levels were estimated by Friedewald's formula: LDL-c $=$ TC $(\mathrm{HDL}+\mathrm{TG})$ if triglycerides $\leq 400 \mathrm{mg} / \mathrm{dl}$. The cutoff points adopted to assess lipid levels were based on the IV Brazilian Guidelines for Dyslipidemia ${ }^{16}$.

\section{- Anthropometric measures}

The students wore light, disposable clothing, made of Kami fabric, and removed their footwear and personal items such as hair clips, glasses, watches, bracelets, rings and necklaces. Weight was measured in kilograms, using a Tec 30 digital scale (Techline), certified by the Metrology Institute (InMetro), with $0.1 \mathrm{~kg}$ resolution and maximum and minimum capacity of $150 \mathrm{~kg}$ and $2.5 \mathrm{~kg}$, respectively. A $0.5 \mathrm{~cm}$-graduated wooden ruler of an Alturexata portable stadiometer coupled to a base was used to measure height, in meters ${ }^{17}$.

These two measures were used to determine body mass index (BMI), by dividing weight in $\mathrm{kg}$ by height in meters squared - BMI = weight $(\mathrm{kg})$ / height ${ }^{2}\left(\mathrm{~m}^{2}\right)$. The values recommended by the WHO (in $\left.\mathrm{kg} / \mathrm{m}^{2}\right)$ were used as parameters, as follows: low weight $<18.5$; normal weight $18.5-24.9$; overweight $\geq 25$ to 29.9 ; grade I obesity 30.0 to 34.9 ; grade II obesity 35.0 to 39.9 and grade III obesity $\geq 40.0^{18}$.

To determine waist circumference (WC), the undergraduates were asked to stand upright, breathe normally, with arms held at the sides, feet together, and backs to a horizontal mirror, $1.20 \mathrm{~cm}$ wide and $1 \mathrm{~m}$ high. The measurement site was the midpoint between the lower edge of the costal arch and the right iliac crest ${ }^{19-20}$.

Measures of weight, height and WC were used to determine abdominal obesity by means of the conicity index $(\mathrm{CI})^{21}$, adopting the following cutoff points for women: abdominal obesity $=0$ if $\mathrm{CI}<1.18$ and abdominal obesity $=1$ if $\mathrm{CI}>=1.18^{22}$.

\section{Analysis procedures}

The database was prepared using SPSS software, version 20.0 and exported to STATA statistical software, version 12.0 where data were analyzed.

Sociodemographic data were characterized in percentages. The mean and standard deviation were calculated for the anthropometric variables and sitting time during the week and over the weekend. Prevalence of overweight, obesity, abdominal obesity and lipid disorders were estimated.

Predictive power, in addition to sitting time cutoff points for the presence of overweight, obesity and abdominal obesity were identified using 
Receiver Operating Characteristic (ROC) curves, often used to determine cutoff points in diagnostic or screening tests ${ }^{23}$.

Initially, the total area under the ROC curve between sitting time on a weekday and the weekend and the presence of overweight, obesity, abdominal obesity and lipid disorders were identified. The larger the area under the ROC curve, the greater the discriminatory power for the presence of overweight, obesity, abdominal obesity and lipid disorders. A confidence interval (CI) of $95 \%$ was used. A CI of $95 \%$ determines whether the predictive capacity of sitting time is not random, and its lower limit should be no lower than $0.50^{24}$.

Cutoff points were then determined, along with their respective sitting time (hours/day) sensitivity and specificity for the presence of overweight, obesity, abdominal obesity and lipid disorders. Cutoff points were identified according to the most suitable balance between sensitivity and specificity.

\section{RESULTS}

The data of the 137 nursing students who underwent anthropometric assessment and responded to questions regarding sitting time were analyzed. Of these 83 (60.1\%) were enrolled in the first year of the course and 55 (39.9\%) in the last. The means and percentages of anthropometric variables, sitting time and proportions of age group, excess weight and lipid disorder are shown in the table 1.

Table 1 - Means, standard deviation and $95 \% \mathrm{Cl}$ of anthropometric variables, sitting time and proportions of age group, excess weight and lipid disorders in undergraduate nursing $(n=137)$. Salvador-BA, 2011.

\begin{tabular}{|c|c|}
\hline Variables & \\
\hline Weight (kg) & $62.4 \pm 9.8(45.1-90.0)$ \\
\hline Height (m) & $1.63 \pm 0.06(1.47-1.83)$ \\
\hline Waist circumference (cm) & $80.3 \pm 8.2(62-106.5)$ \\
\hline BMI $\left(\mathrm{kg} / \mathrm{m}^{2}\right)$ & $23.4 \pm 3.36(17.1-39.0)$ \\
\hline \multicolumn{2}{|l|}{ Sitting time (hours/day) } \\
\hline Weekday & $8.3 \pm 3.2(2-19)$ \\
\hline Weekend & $8.2 \pm 4.3(1-20)$ \\
\hline \multicolumn{2}{|l|}{ Age } \\
\hline 18 to 19 years & $35(25.4 \%)$ \\
\hline 20 to 24 years & $74(54.4 \%)$ \\
\hline 25 and older & $28(20.2 \%)$ \\
\hline $\begin{array}{l}\text { Overweight } \\
\text { (BMI } \geq 25 \text { to } 29.9 \mathrm{~kg} / \mathrm{m}^{2} \text { ) }\end{array}$ & $32(24.4 \%)$ \\
\hline $\begin{array}{l}\text { Obesity I and II } \\
\text { (BMI } 30 \text { to } 39.9 \mathrm{~kg} / \mathrm{m}^{2} \text { ) }\end{array}$ & $06(4.4 \%)$ \\
\hline Abdominal obesity $(\mathrm{WC} \geq 80 \mathrm{~cm}$ ) & $76(55.5 \%)$ \\
\hline \multicolumn{2}{|l|}{ Altered lipid profile } \\
\hline $\mathrm{TC}(\geq 240 \mathrm{mg} / \mathrm{dl})$ & $05(3.6 \%)$ \\
\hline TG ( $200-499$ mg/dl) & $01(0.7 \%)$ \\
\hline LDL-C ( $\geq 160-189$ mg/dl) & $03(2.2 \%)$ \\
\hline $\mathrm{HDL}-\mathrm{C}(<40 \mathrm{mg} / \mathrm{dl})$ & $04(2.9 \%)$ \\
\hline
\end{tabular}

kg, kilogram; m, meter; cm, centimeter; BMI, body mass index; WC, waist circumference; TC; total cholesterol; TG, triglycerides; LDL-C, Low density lipoprotein; HDL-C, High density lipoprotein 
Table 2 illustrates the areas under the ROC curve of sitting time as discriminator of overweight, obesity and abdominal obesity in undergraduate students. It was found that sitting time during the week is a good discriminator of abdominal obesity, but no areas under the ROC curve were statistically significant for discriminating overweight and obesity. Furthermore, sitting time on the weekend did not exhibit discriminatory power for overweight, obesity or abdominal obesity.

Table 2. Area under the ROC curve and $95 \% \mathrm{Cl}$ of sitting time as discriminator of overweight, obesity and abdominal obesity in undergraduate nursing ( $n=137)$. Salvador - BA, 2011.

\begin{tabular}{lccc}
\hline & Overweight & Obesity & Abdominal obesity \\
\hline Sitting time & & & \\
Weekday & $0.47(0.36-0.58)$ & $0.50(0.30-0.71)$ & $0.66(0.57-0.75)^{\star}$ \\
Weekend & $0.48(0.37-0.59)$ & $0.34(0.16-0.51)$ & $0.52(0.42-0.62)$ \\
\hline
\end{tabular}

$\mathrm{ROC}=$ receiver operating characteristic; $95 \% \mathrm{Cl}=95 \%$ confidence interval.

${ }^{*}$ Area under the ROC curve exhibiting discriminatory power for overweight, obesity and abdominal obesity $(\mathrm{Li}-\mathrm{Cl} \geq 0.50)$.

Table 3 shows that sitting time during the week or on the weekend did not discriminate lipid disorders (TG, TC, LDC-C and HDL-C).

Table 3. Area under the ROC curve and $\mathrm{Cl} 95 \%$ of sitting time as a discriminator of lipid disorders in undergraduate nursing $(n=137)$. Salvador - BA, 2011.

\begin{tabular}{lcccc}
\hline & TG & TC & LDL-C & HDL-C \\
\hline Sitting time & \multicolumn{4}{c}{} \\
Weekday & 0.73 & 0.62 & 0.54 & 0.67 \\
& $(0.00-1.00)$ & $(0.34-0.90)$ & $(0.06-1.00)$ & $(0.23-1.00)$ \\
\multirow{2}{*}{ Weekend } & 0.38 & 0.44 & 0.44 & 0.63 \\
& $(0.00-1.00)$ & $(0.19-0.69)$ & $(0.00-0.88)$ & $(0.39-0.88)$ \\
\hline
\end{tabular}

ROC = receiver operating characteristic; $95 \% \mathrm{Cl}=95 \%$ confidence interval; TG, Triglycerides; TC, Total cholesterol; LDL-C, Low density lipoprotein; HDL-c, High density lipoproteins.

Figure 1 contains the cutoff point and its respective sensitivity and specificity of sitting time as discriminator of overweight, obesity and abdominal obesity in undergraduate students. It was observed that sitting for 8 hours a day during the week discriminates the presence of abdominal obesity.

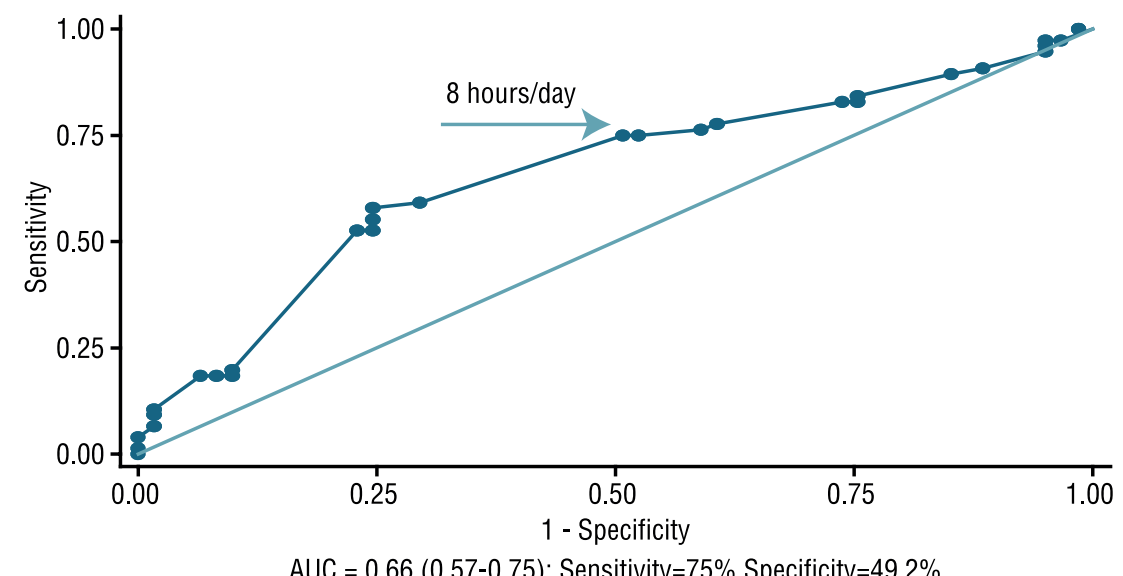

Figure 1. Area under the ROC curve, cutoff point, sensitivity and specificity of sitting time during the week as discriminator of abdominal obesity in nursing undergraduate $(n=137)$. Salvador (BA), 2011. 


\section{DISCUSSION}

The study sought to demonstrate the discriminatory power and cutoff points of sitting time for overweight, obesity, abdominal obesity and lipid disorders in undergraduate students. It is important to underscore that only one study was found on this topic that used ROC curves as an analytical method. Therefore, our comparisons were made primarily with association or intervention studies.

This recent research showed that the screen time largest or equal to 4 hours a day is a good discriminator of overweight in adolescents ${ }^{10}$. Important to clarify that this study was analyzed only screen time, while in this study was analyzed the total sitting time, including not only screen time, but also the sitting time in performing other sedentary activities.

Another prospective study ${ }^{2}$ conducted in women to examine the relationship between a number of sedentary behaviors and the risk of obesity and type 2 diabetes mellitus found that different sedentary behaviors, especially watching television, were significantly associated with a high risk of obesity.

Our study showed that time spent sitting during the week discriminates only abdominal obesity in undergraduate nursing and that 8 hours/day is the cutoff point for this fact to occur. It is important to underscore that time spent sitting on the weekend did not exhibit discriminatory power for overweight, obesity or abdominal obesity. Despite the amount hours sitting for one day at the week be equal the number of sitting hours during a day at the weekend between the study participants, the actions taken may be different, especially with regard to breaks in sitting time during the weekend, fact that may have contributed to the discriminatory power was not observed during the weekend.

Regarding the cutoff point of 8 hours a day is important to note that in a study conducted in Australia revealed that sitting more than 8 hours a day increases mortality from all causes in adults ${ }^{7}$.

In another prospective study carried out in Australia, it was observed that overweight and obese women showed a greater weight variation between 2000-2006 in those whose sitting time increased than in those where it declined, demonstrating that sitting time can influence obesity. On the other hand, the change in sitting time was significantly higher in individuals who gained weight compared to those who experienced weight loss ${ }^{8}$. These results confirm the association between simultaneous changes in weight and sitting time in overweight and obese women, but in this study prospective associations were found.

In another study conducted in Australia it was demonstrated that the combination of prolonged sitting time and little physical activity was the most associated with adult obesity ${ }^{9}$. The mechanisms by which prolonged sitting time influences obesity and abdominal obesity are related to reduced lipoprotein lipase (LPL) activity, which decreases plasma triglyceride absorption, primarily by skeletal muscles ${ }^{12}$. Low LPL activity levels were 
associated with a substantial decrease in plasma triglyceride absorption by skeletal muscles. Thus, fats are deposited in the vessels or adipose tissue, primarily in the visceral abdominal area ${ }^{12}$. In our study, we observed discriminatory power of sitting time just to abdominal obesity probably because this tissue is more susceptible to the action of LPL after longer periods of sitting time.

In this sense, considering studies with rats, there is evidence that muscle inactivity leads to a decline in lipoprotein lipase (LPL) enzyme activity, whose role is to regulate triglyceride absorption in muscles ${ }^{25}$. The absence of contraction in lower limb muscles specialized in maintaining posture is associated with a $75 \%$ reduction in the absorption of fat in the bloodstream ${ }^{26}$.

On the other hand, a number of authors suggest that screen-based sedentary behavior, mainly watching television, can lead to higher calorie intake due to a wide range of mechanisms that increase food consumption, particularly in adolescents ${ }^{27-28}$. In our study, this fact likely had no influence, since we found discriminatory power for abdominal obesity only for sitting time during the week, which would be associated with hours of study, both at the university and at home.

In relation to lipid profile in a study conducted in Taiwan ${ }^{4}$ with 2353 subjects of both sexes, aged approximately 40 years, it was observed that prolonged television viewing is an independent risk factor for metabolic syndrome. Another recent systematic review study demonstrated associations between sedentary behavior and different health outcomes, Including the lipid profile, in adults in general ${ }^{15}$. In the present study we were unable to demonstrate the discriminatory power of sitting time for lipid disorders, likely by virtue of the low age range of the participants (mean of 22 years). It is important to underscore that abdominal obesity may be present for several years before lipid disorders and other unfavorable outcomes emerge $\mathrm{e}^{29-30}$.

The main limitations of this study are the convenience sampling and sample size. Furthermore, the study sample consisted only of women and this type of investigation can assess other groups of university students. In addition, although the sensitivity value (75\%) found for the cutoff point of 8 hours per week was considered good, the specificity of only (49.2\%) may generate false negatives in the discrimination of abdominal obesity in university students. The strong point of the study is the use of ROC curves as a method of analysis, since only one work with this methodology was located in the consulted literature $\mathrm{e}^{10}$

\section{CONCLUSIONS}

The results obtained here suggest that sitting time during the week discriminates abdominal obesity in undergraduate nursing. The cutoff point for cumulative sitting time on a weekday to discriminate abdominal obesity is 8 hours/day. This fact highlights the importance of adopting measures to 
prevent and control this risk factor during academic life. Equally important is encouraging healthy behavior in the training of future health professionals. It is recommended that higher education institutions implement measures to reduce the sitting time of students, especially during the week.

\section{REFERENCES}

1. Jakes RW, Day NE, Khaw KT, Luben R, Oakes S, Welch A, et al. Television viewing and low participation in vigorous recreation are independently associated with obesity and markers of cardiovascular disease risk: EPIC-Norfolk populationbased study. Eur J Clin Nutr 2003; 57(9):1089-96.

2. Hu FB, Li TY, Colditz GA, Willett WC, Manson JE. Television watching and other sedentary behaviors in relation to risk of obesity and type 2 diabetes mellitus in women. JAMA 2003; 289(14):1785-91.

3. Banks E, Jorm L, Rogers K, Clements M, Bauman A. Screen-time, obesity, ageing and disability: findings from 91266 participants in the 45 and Up Study. Public Health Nutr 2011;14(1):34-43.

4. Chang PC, Li TC, Wu MT, Liu CS, Li CI, Chen CC et al. Association between television viewing and the risk of metabolic syndrome in a community-based population. BMC Public Health 2008; 3;8:193.

5. Stamatakis E, Hamer M, Dunstan DW. Screen-based entertainment time, allcause mortality, and cardiovascular events: population-based study with ongoing mortality and hospital events follow-up. J Am Coll Cardiol 2011; 57(3):292-9.

6. Dunstan DW, Barr EL, Healy GN, Salmon J, Shaw JE, Balkau, et al. Television viewing time and mortality: the Australian Diabetes, Obesity and Lifestyle Study (AusDiab). Circulation 2010;121(3):384-91.

7. Van der Ploeg HP, Chey T, Korda RJ, Banks E, Bauman A. Sitting time and all-cause mortality risk in 222497 Australian adults. Arch Intern Med 2012; 26;172(6):494-500.

8. De Cocker KA, van Uffelen JG, Brown WJ. Associations between sitting time and weight in young adult Australian women. Prev Med 2010;51(5):361-7.

9. Sugiyama T, Healy GN, Dunstan DW, Salmon J, Owen N. Joint associations of multiple leisure-time sedentary behaviours and physical activity with obesity in Australian adults. Int J Behav Nutr Phys Act 2008;5:35.

10. Pitanga FJG, Alves CFA, Pamponet, ML, Medina, MG, Aquino R. Tempo de tela como discriminador de excesso de peso, obesidade e obesidade abdominal em adolescentes. Rev Bras Cineantropom Desempenho Hum 2016; 18 (5): 539-47.

11. Su C, Jia XF, Wang ZH, Wang HJ, Ouyang YF, Zhang B. Longitudinal association of leisure time physical activity and sedentary behaviors with body weight among Chinese adults from China Health and Nutrition Survey 2004-2011. Eur J Clin Nutr (In press).

12. Edwardson CL, Gorely T, Davies MJ, Gray LJ, Khunti K, Wilmot EG, Yates T,Biddle SJ. Association of sedentary behaviour with metabolic syndrome: a metaanalysis. PLoS One 2012; 7(4): e34916.

13. Quadros TM, Petroski EL, Silva DA, Pinheiro-Gordia AThe prevalence of physical inactivity amongst Brazilian university students: its association with sociodemographic variables. Rev Salud Pública 2009;11(5):724-33.

14. Rangel Caballero LG, Rojas Sánchez LZ, Gamboa Delgado EM. Overweight and obesity in Colombian college students and its association with physical activity. Nutr Hosp 2014;31(2):629-36.

15. Rezende LFM, Lopes MR, Rey-Lopez JP, Matsudo VKR, Luiz OC. Sedentary Behavior and Health Outcomes: An Overview of Systematic Reviews. PLoS ONE 2014; 9(8): e105620. 
16. Sposito AC. IV Diretriz brasileira sobre dislipidemias e prevenção da aterosclerose. Departamento de Aterosclerose da Sociedade Brasileira de Cardiologia. Arq Bras Cardiol 2007; 88(Supl 1):2-19.

17. Lothman TG, Roche AF, Martorell R. Anthropometric Standardization Reference Manual. Human Kinectis: Champaing, IL, USA,1998.

18. World Health Organization. Obesity: preventing and managing the global epidemic. Report of a World Health Organization Consultation. Geneva, 2000.

19. Institute of Health. National Heart, Lung and Blood Institute. Multi - ethnic study of atherosclerosis (MESA): field center manual of operations. Sealttle, 2001.

20. Alberti KG, Zimmet P, Shaw J. IDF epidemiology task force consensus group. The IDF consensus worldwide definition of metabolic syndrome. Lancet 2005;366(9491):1059-62.

21. Valdez R. A simple model-based index of abdominal adiposity. J Clin Epidemiol 1991;44(9):955-6.

22. Pitanga FJ, Lessa I. Anthropometric indexes of obesity as an instrument of screening for high coronary risk in adults in the city of Salvador-Bahia. Arq Bras Cardiol 2005;85(1): 26-31.

23. Erdreich LS, Lee ET. Use of relative operating characteristics analysis in epidemiology: a method for dealing with subjective judgment. Am J Epidemiol 1981; 114 (5):649-62.

24. Schisterman EF, Faraggi D, Reiser B, Trevisan M. Statistical inference for the area under the receiver operating characteristic curve in the presence of random measurement error. Am J Epidemiol 2001;154(2): 174-9.

25. Bey L, Hamilton MT. Suppression of skeletal muscle lipoprotein lipase activity during physical inactivity: a molecular reason to maintain daily low intensity activity. J Physiol 2003; 551(Pt 2):673-82.

26. Bey L, Akunuri N, Zhao P, et al. Patterns of global gene expression in rat skeletal muscle during unloading and low intensity ambulatory activity. Physiol Genomics 2003;13(2):157-67.

27. Thivel D, Aucouturier J, Doucet E, Saunders TJ, Chaput JP. Daily energy balance in children and adolescents: does energy expenditure predict subsequent energy intake? Appetite 2013; 60(1):58-64.

28. Pearson N, Biddle SJ. Sedentary behavior and dietary intake in children, adolescents, and adults: a systematic review. Am J Prev Med 2011;41:178e88.

29. Després JP. Health consequences of visceral obesity. Ann Med 2001;33(8):534-41.

30. Caballero AE. Endothelial dysfunction in obesity and insulin resistance: a road to diabetes an heart disease. Obes Res 2003;11(11):1278-89.

\section{CORRESPONDING AUTHOR}

Fernanda C Mussi

Universidade Federal da Bahia Rua Dr. Augusto Viana Filho, Campus Universitário do Canela, Escola de Enfermagem CEP 40110 60, Salvador, Bahia, Brasil E-mail: femussi@uol.com.br 